\title{
Article \\ Evaluation of Dietary Curcumin Nanospheres in a Weaned Piglet Model
}

\author{
Mohammad Moniruzzaman ${ }^{1,+}+\mathbb{D}$, Hunhwan Kim ${ }^{2,+}{ }^{+}$Haewon Shin ${ }^{1}$, Hyunsoo Kim ${ }^{1}$, Nayoung Kim ${ }^{1}(\mathbb{D}$,

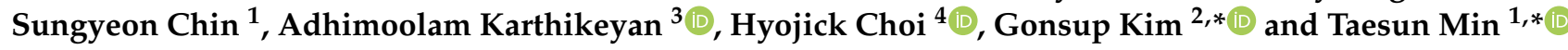 \\ 1 Department of Animal Biotechnology, Jeju International Animal Research Center (JIA) \& Sustainable \\ Agriculture Research Institute (SARI), Jeju National University, Jeju 63243, Korea; \\ monir1983@jejunu.ac.kr (M.M.); jjkanji23@naver.com (H.S.); rlagustn9891@naver.com (H.K.); \\ skdud559@naver.com (N.K.); syeun77777@naver.com (S.C.) \\ 2 Research Institute of Life Science and College of Veterinary Medicine, Gyeongsang National University, \\ Gazwa, Jinju 52828, Korea; shark159753@naver.com \\ 3 Subtropical Horticulture Research Institute, Jeju National University, Jeju 63243, Korea; \\ karthik2373@gmail.com \\ 4 Sustainable Engineering \& Drug Delivery Design Lab, Department of Chemical and Materials Engineering, \\ University of Alberta, Edmonton, AB T6G 2V4, Canada; hyojick@ualberta.ca \\ * Correspondence: gonskim@gnu.ac.kr (G.K.); tsmin@jejunu.ac.kr (T.M.); Tel.: +82-55-772-2356 (G.K.); \\ +82-64-754-8347 (T.M.) \\ + These authors contributed equally to this work.
}

Citation: Moniruzzaman, M.; Kim, H.; Shin, H.; Kim, H.; Kim, N.; Chin, S.; Karthikeyan, A.; Choi, H.; Kim, G.; Min, T. Evaluation of Dietary Curcumin Nanospheres in a Weaned Piglet Model. Antibiotics 2021, 10, 1280. https://doi.org/10.3390/ antibiotics 10111280

Academic Editor: Carlo Corino

Received: 21 September 2021

Accepted: 17 October 2021

Published: 20 October 2021

Publisher's Note: MDPI stays neutral with regard to jurisdictional claims in published maps and institutional affiliations.

Copyright: (c) 2021 by the authors. Licensee MDPI, Basel, Switzerland. This article is an open access article distributed under the terms and conditions of the Creative Commons Attribution (CC BY) license (https:// creativecommons.org/licenses/by/ $4.0 /)$.

\begin{abstract}
Curcumin is a polyphenolic compound present in turmeric with extensive uses in cooking foods and biomedical applications. However, due to its hydrophobic nature, it is poorly soluble in water and its bioavailability is very low on oral administration in organisms. In this study, we investigated the dietary curcumin nanospheres in a weaned piglet model based on the growth, serum biochemistry, proteomics, fecal coliform bacteria, and malodors in the feces of piglets. A total of 135 weaned piglets (Duroc $\times$ [Yorkshire $\times$ Landrace]) with an average initial body weight of $7.0 \pm 1.0 \mathrm{~kg}$ ( $28 \pm 1$ days of age) were randomly distributed in 9 pens (15 pigs in each pen) fed the dietary curcumin nanospheres $(\mathrm{CN})$ at 0 (control), $0.5(\mathrm{~T} 1)$, and $1.0 \mathrm{~mL}(\mathrm{~T} 2) \mathrm{CN} / \mathrm{kg}$ of diet in triplicates for 21 days. At the end of the feeding trial, the results showed piglets fed $1.0 \mathrm{~mL} \mathrm{CN} / \mathrm{kg}$ diet had significantly higher growth performance and feed utilization than control diet (without CN). However, there were no significant differences in growth and feed utilization between piglets fed T1 and T2 diets. Serum glucose, gamma-glutamyl transferase, total bilirubin, amylase, and lipase contents were unaffected in piglets fed the experimental diets. Interestingly, piglets fed T1 and T2 diets showed significantly lower total cholesterol levels than control diet. In serum proteomics, a total of 103 differentially expressed proteins (DEPs) were identified in the piglets fed control, T1, and T2 diets, of which 14 DEPs were upregulated and 4 DEPs were downregulated. Fecal coliform bacteria and ammonia gas were significantly reduced in piglets fed T1 and T2 diets. Overall, the results indicated dietary supplementation of $\mathrm{CN}$ could enhance the growth, feed utilization, and immunityand reduce fecal pathogenic bacteria as well as ammonia gas emissions-in weaned piglets.
\end{abstract}

Keywords: nanomedicine; alternative of antibiotics; growth; hematology; proteomics; coliform bacteria; noxious gas; piglet

\section{Introduction}

Curcumin is a lipophilic polyphenolic phytocompound present in the herbal plant, Curcuma longa which has been widely used as turmeric powder in Southeast Asian countries [1]. Curcumin has been reported to act as a potential therapeutic agent due to its antioxidant, anti-inflammatory, antimicrobial, and anticancer activities [2-4]. For its therapeutic significance, curcumin would treat or prevent different types of ailments such as arthritis, enteritis, stomach ulcers, wounds, acne, skin lesions, neurodegeneration, 
and cancers [5]. The turmeric plant is known to contains nearly about 3-6\% of highly bioactive curcumin with low toxicity in the form of diferuloylmethane [1,7-bis(4-hydroxy3-methoxyphenyl)-1,6-heptadiene-3,5-dione] in a dry condition and generally regarded as safe (GRAS) by United States Food Drug Administration (USFDA) [6,7]. For centuries, curcumin has been widely used as Ayurvedic herbal medicine in India and China [5]. However, curcumin has low solubility in water, rapid excretion, but poor absorption and bioavailability in organisms, making its utilization challenging [8]. About $75 \%$ of curcumin can be excreted from feces after its oral administration in rats [9]. For this, a significant number of studies have been conducted to increase the solubility and bioavailability of curcumin in the form of nanoparticles or nanocurcumin in relation to the normal curcumin [10-14]. Nanopharmaceutics or nanomedicines are usually developed on the nanosize and its physicochemical characteristics, pharmacokinetics as well as biological activity at molecular level [15]. In this regard, nanocurcumin which coined as particle sizes of curcumin with less than $1 \mu \mathrm{m}$, has a great importance as nanomedicine in pharmaceutical and biomedical science [16]. However, the nanosizing of curcumin and its effective delivery in organisms is the prime concern in suggesting the potentiality of nanocurmin. In this case, the use of carrier vesicles or nanocarriers could offer a promising approach in terms of effective biodistribution of nanocurcumin as an active pharmaceutical ingredient (API) in organisms [15]. Specifically, curcumin can be encapsulated in nanocarriers such as nanoemulsions, nanoliposomes, solid lipid nanoparticles (SLNs), or polymer-based techniques (i.e., PLGA nanoparticles, biopolymers, hydrogels, or nature-inspired techniques like casein and cyclodextrins) [7,17-22]. According to a report, PLGA-nanocurcumin at 15 -fold lower concentration is superior to poorly soluble native curcumin in therapeutic application [23], while another study suggested that encapsulation of nanocurcumin is 9-times more suitable than native curcumin in terms of oral bioavailability in animals [24]. Verma et al. [25] concluded that liposomal nanocarriers are highly biocompatible and can entrap hydrophobic pharmaceuticals in the membrane. In other studies, hydrophobic nanocurcumin with liposomal nanocarriers are found to be highly effective in biomedical applications [26-28]. Liposomal nanoparticles consisting in phosphatidylcholine or phosphatidylserine and containing curcumin exerted their potential in terms of oral delivery for bioavailability, antioxidant properties, and treatment of hepatic fibrosis [26,29].

Numerous studies have been conducted to investigate the biomedical applications of nanocurcumin with different nanocarriers using in vitro cell lines or in vivo murine models [30]. However, little is known about the utilization of nanocurcumin in large animal models [31,32]. Importantly, swine has been discussed as a promising monogastric large animal in investigating digestive physiology, immunology, and toxicology concerning human diseases [33-35]. According to a study, a pig's immune system is about $80 \%$ similar to that of a human being in comparison to a mouse-which resembles only about $10 \%$ making pigs an excellent model for testing the effect of nanocurcumin in humans along with the fact that pigs can be easily bred compared to other large animals like monkeys and dogs [34]. In the life cycle of pig, young pigs experience diarrheal problems, complications in the gastrointestinal tract (GIT), and stunted growth with high morbidity and mortality during their weaning [36]. In addition, pig farms are a major source of noxious gases such as ammonia $\left(\mathrm{NH}_{3}\right)$ and hydrogen sulfide $\left(\mathrm{H}_{2} \mathrm{~S}\right)$, which affect the air quality of the surrounding areas including human livelihoods. Therefore, it is of the utmost importance to determine a suitable way to enhance the growth and immunity-and reduce the diarrheal problem - in young piglets and reduce fecal malodors from the pig farms. In this regard, we consider curcumin nanospheres $(\mathrm{CN})$ a potent treatment for them, as Liu et al. [37] and Kim et al. [38] postulated that dietary plant extracts have significant positive effects on immune responses in their proteomics analyses of weaned pigs.

In the recent studies of our research group, we have reported the positive effects of curcumin nanospheres $(\mathrm{CN})$ on using in vitro cell lines and in vivo mouse model $[39,40]$ including the physicochemical characteristics and pharmacokinetics in terms of size, solubility, efficiency, drug delivery, and bioavailability of CN [41]. In the present study, we 
envisage to evaluate the dietary effects of curcumin nanospheres with pharmacodynamics in weaned piglets as a large monogastric animal model based on growth performance, serum biochemistry, serum proteomic analysis, fecal coliform bacteria contents and fecal malodors in feces.

\section{Materials and Methods}

\subsection{Ethics Statement}

The experiment was followed under the guidelines of Institutional Animal Care and Use Committee of the Jeju National University, Jeju, Korea (approval number: 2021-0055). Every effort was taken to minimize animal suffering.

\subsection{Chemicals and Reagents}

Curcumin powder (from Curcuma longa, turmeric plant) and lecithin (in the form of L- $\alpha$-phosphatidylcholine from egg yolk) were purchased from Sigma-Aldrich (St. Louis, MO, USA). The organic solvents, toluene (anhydrous, 99.8\%) and dichloromethane (DCM, 99.9\%), were obtained from Sigma-Aldrich (St. Louis, MO, USA) and Acros Organics (Janssen Pharmaceuticals, Geel, Belgium), respectively. All other chemicals and reagents were analytical grade.

\subsection{Preparation of Curcumin Nanospheres (CN)}

Curcumin nanospheres were produced as described in previous reports [39-41]. Briefly, $100 \mathrm{mg}$ curcumin powder was dissolved in $20 \mathrm{~mL}$ toluene as organic solvent and then the solution was added dropwise in $1 \mathrm{~L}$ distilled water on heating mantle with continuous ultrasonication at a frequency of $50 \mathrm{kHz}$ for $3 \mathrm{~h}$. The sonication process was operated within an insulated sonication box with sonicating probe (Sonictopia, Rep. of Korea) to reduce hazardous effects of ultrasonication on the outside environment. After sonication, the solution was stirred for $20 \mathrm{~min}$ on the heating mantle with a magnetic stirrer. The solution was then transferred to a rotary evaporator (Buchi AG, Meierseggstrasse, Flawil, Switzerland) and concentrated the solution at the evaporating temperature of $40{ }^{\circ} \mathrm{C}$. The concentrated solution was freeze dried for $72 \mathrm{~h}$ to obtain nanocurcumin powder. For the production of curcumin nanospheres, $200 \mathrm{mg}$ of lecithin was dissolved in $40 \mathrm{~mL}$ dichloromethane (DCM) and then $40 \mathrm{mg}$ of the nanocurcumin powder was mixed with the lecithin-DCM solution (1 mg of nanocurcumin powder with $5 \mathrm{mg}$ lecithin/ $\mathrm{mL}$ DCM). The mixture was ultrasonicated for $2 \mathrm{~h}$ at $20-30 \mathrm{kHz}$ to achieve an orange-colored curcumin nanospheres $(\mathrm{CN})$ solution. The $\mathrm{CN}$ solution was stored in falcon tubes at $-70^{\circ} \mathrm{C}$ until used in the feeds of weaned piglets. The $\mathrm{CN}$ was produced at large scale to execute the in vivo experiment in weaned piglets. Furthermore, morphology and characteristics of $\mathrm{CN}$ was described by Kim et al. [39].

\subsection{Addition of $\mathrm{CN}$ in the Diets of Piglets}

A commercial powder diet (Neopigg, Purina Korea) contained with all the nutritional requirements (protein, 23.0\%; lipid, 5.5\%; ash, 8.0\%; fiber, 4.0\%; digestible energy, $3.6 \mathrm{Mcal} / \mathrm{kg}$ ) for weaned piglets was used as the control without supplementation of $\mathrm{CN}$. Two other diets were prepared with dropwise mixing of $\mathrm{CN}$ at $0.5 \mathrm{~mL} / \mathrm{kg}$ (T1) and $1.0 \mathrm{~mL} / \mathrm{kg}$ (T2) in the powder of control diet using a mixer based on Marcon et al. [31]. The diets were then dried at $25^{\circ} \mathrm{C}$ room temperature (RT) for $72 \mathrm{~h}$ to remove the DCM in the diets. The three diets were then packed in airtight bags labeled with the diet numbers.

\subsection{Animals and Experimental Design}

A total of 135 purchased weaned piglets (Duroc $\times$ [Yorkshire $\times$ Landrace]) with an average initial body weight of $7.0 \pm 1.0 \mathrm{~kg}$ and $28 \pm 1$ days of age were used in this study. The experiment was executed in a local pig farm (Bada Pig Farm, Hallim, Jeju, Korea. The piglets were randomly distributed into 3 groups in triplicates ( 15 piglets/pen and 45 piglets/treatments) according to the designated diets of the control, T1, and T2. All 
the piglets were marked by numbers on the skin with permanent red ink marker for easy identification during sampling and the pens were equipped with drinking water, controlled temperature, feed supply, and drainage facilities. The piglets were fed the experimental feeds and water ad libitum. The temperature in the rearing pens was maintained at $28.0 \pm 1.0^{\circ} \mathrm{C}$ throughout the experimental period.

\subsection{Sample Collection and Analyses of Piglets}

\subsubsection{Growth Parameters}

At the end of the 21-day feeding trial, the weights of the piglets were measured individually in weight cages according to the pen number and treatment group numbers following the weight gain (WG), average daily gain (ADG), feed intake (FI), average feed intake (ADFI), feed efficiency (FE), and feed conversion ratio (FCR) were calculated based on initial weight, final weight (FW), and daily feed intake data. Fresh fecal samples were obtained from each pen of the treatment groups based on the dietary treatments.

\subsubsection{Serum Biochemical Composition}

For examining the serum biochemistry, blood samples from the jugular vein of 3 pigs (based on average weight) in each pen of the three treatment groups were collected for biochemical analyses. All of the samples were allowed to rest for few minutes at room temperature (RT), followed by centrifugation $1500 \times g$ at $4{ }^{\circ} \mathrm{C}$ for $20 \mathrm{~min}$ [42]. The supernatant of each blood sample (blood serum) was collected by micropipette and kept in a microtube at $-20{ }^{\circ} \mathrm{C}$ until analyzed. The serum biochemistry in terms of glucose (Glu), creatinine (CRT), blood urea nitrogen (BUN), inorganic phosphorus (IP), calcium (Ca), total protein (T-Pro), albumin (ALB), globulin (GLB), alanine aminotransferase (ALT), alkaline phosphatase (ALKP), gamma-glutamyl transferase (GGT), total bilirubin (TBIL), total cholesterol (TCHOL), amylase (AMYL), and lipase (LYPS) was determined by commercial kits using a blood biochemical analyzer (Refloton Plus, Hoffmann-La Roche, Rotkreuz, Switzerland).

\subsubsection{Serum Proteome Analysis}

Sample Preparation

For serum proteomic analysis, an aliquot $(5 \mathrm{~mL})$ of collected blood serum was analyzed based on the dietary treatments in the weaned piglets. For this, the serum samples were subjected to a gene ontology (GO) study followed by Kim et al. [43]. The protein concentrations in the serum samples were analyzed by using a bicinchoninic acid (BCA) assay kit (Pierce BCA protein assay kit, Thermo Fisher Scientific). Afterward, the samples with the same concentrations of protein were used for proteomic analysis.

\section{Gel Electrophoresis}

For one-dimensional SDS-PAGE, a total of $20 \mu \mathrm{g}$ of proteins from the pig serum were diluted with a denaturing sample buffer ( $0.5 \mathrm{M}$ Tris- $\mathrm{HCl} \mathrm{pH} 8.8,10 \%$ SDS, $20 \%$ glycerol, $1 \%$ bromophenol blue, $0.2 \%$ DTT), and heated at $95{ }^{\circ} \mathrm{C}$ for $5 \mathrm{~min}$. Then the samples were transferred to a gel electrophoresis unit for SDS-PAGE. The gel was then stained with Coomassie Brilliant R250 (Sigma-Aldrich, ST. Louis, MO, USA) and de-stained with water [44]. All protein bands after the electrophoresis were excised using a razor blade from top to bottom, and the excised gel slices were washed twice with $100 \mu \mathrm{L}$ of distilled water for $15 \mathrm{~min}$ at RT. The dried gel slices were then stored at $-80^{\circ} \mathrm{C}$ for further analysis.

\section{Nano-LC-MS/MS Analysis}

The dried peptides on the gel slices were dissolved in $20 \mu \mathrm{L}$ of $5 \%$ formic acid and analyzed using nanoflow LC-MS/MS. All nano-LC-MS/MS experiments were performed on an Ekisigent nanoLC415 system (EKsigent, Dublin, CA, USA). For a gel-free proteomic analysis, the protein samples were re-suspended in a water/formic acid solution (water in 
5\% formic acid). Online NanoHPLC was conducted using an Ekisigent nanoLC415 system (EKsigent, Dublin, CA, USA).

Data Search and Criteria for Protein Identification

After MS/MS analysis, the data files were processed using the UniProt and Protein Pilot 5.0.1 (SCIEX, Redwood City, CA, USA) database software. Based on the combined MS and MS/MS spectra, the proteins were successfully identified at a $95 \%$ or higher confidence interval, making it possible to use their scores in the MASCOT V2.5 search engine (Matrix Science Ltd., London, UK) and the following search parameters for Sus scrofa (Pig). The database search results were manually curated to yield the protein identifications using $1 \%$ global false discovery rate (FDR) determined by the in-built FDR tool within the ProteinPilot software and Scaffold (version Scaffold_4.8.4, Proteome Software Inc., Portland, OR, USA) was used to validate the MS/MS based peptide and protein identifications. The protein identification was based on $99 \%$ protein threshold and $95 \%$ peptide threshold levels. The differentially expressed proteins (DEPs) were categorized into upregulated and downregulated proteins present in the serum among piglets fed T1 and T2 diets in comparison to the control diet based on the log-fold change criteria, +1 (upregulated proteins) or -1 (downregulated proteins) cut off values.

Gene Ontology (GO) and Enrichment Pathway Analyses

The gene ontology (GO) categories of the serum protein of piglets fed the experimental diets were described based on biological processes, cellular components and molecular functions using Scaffold software. Likewise, all of the functionally enriched pathways of the significantly expressed proteins were determined with using the Kyoto Encyclopedia of Genes and Genomes (KEGG) and REACTOME pathway databases.

\section{Protein-Protein Interaction (PPI) Network Analysis}

The protein-protein interactions (PPI) using the Search Tool for the Retrieval of Interacting Genes (STRING, version 9.1) (http:/ / string-db.org) (accessed on 16 September 2021) was used to determine both physical and functional associations between proteins. The PPI score was set based on medium confidence (0.4). In PPI network, each node depicts a protein, while the edges represent the strength of the relationship between proteins (i.e., more edges give higher confidence). The software Cytoscape was used to visualize the network.

\subsubsection{Fecal Noxious Gases and Pathogenic Bacteria Contents}

The fecal samples collected from the same pen were mixed and stored in airtight plastic bags at $-20^{\circ} \mathrm{C}$ until the measurement of fecal malodors. Parts of the fresh fecal samples were placed in an icebox and pathogenic bacterial load analyses were immediately conducted in the laboratory. Following that, fecal samples in the bags were connected to a specific gas sampling kit for ammonia $\left(\mathrm{NH}_{3}\right)$ and hydrogen sulfide $\left(\mathrm{H}_{2} \mathrm{~S}\right)$ gases and then the fecal gases were measured in ppm (parts per million) by color changes method using a pumping apparatus (model GV-100S; Gastec Corp., Tokyo, Japan). Additionally, the pathogenic bacteria contents, such as Escherichia coli in the fecal samples were detected using the MacConkey agar plate counting method. Briefly, $1 \mathrm{~g}$ of a fecal sample from each pen was diluted and homogenized with $9 \mathrm{~mL}$ peptone water $(15 \mathrm{~g} / \mathrm{L})$ (Oxoid Ltd., Hants, UK) and by vortexing, respectively. The homogenates were serially 10 -fold diluted and spread $(1 \mathrm{~mL})$ on the MacConkey agar $(51.5 \mathrm{~g} / \mathrm{L})$ plates (Oxoid Ltd., Hants, UK) followed by incubation at $37^{\circ} \mathrm{C}$ for $24 \mathrm{~h}$. After incubation, the coliform bacterial colonies were immediately counted using a colony counter and the data were presented in colony forming units per gram of sample (CFU/g).

\subsection{Statistical Analysis}

Piglets pen mean values $(n=3)$ were used for statistical analysis. All the data were subjected to a one-way analysis of variance (ANOVA) test using the SAS version 9.1 
analytical software (SAS Institute, Cary, NC, USA) to test for the dietary treatments. Tukey's HSD (honestly significant difference) post-hoc test was used to compare the means amongst the treatments with significant effects. Data values were expressed as mean \pm standard deviation (SD) of the three replicates of each treatment group. Treatment effects were considered with a significant level of $p<0.05$.

\section{Results}

\subsection{Growth and Feed Intake of Piglets}

The effects of dietary $\mathrm{CN}$ on the growth and feed intake of weaned piglets are presented in Table 1. At the end of the 21-day feeding trial, piglets fed with the T2 diet (1.0 mL CN/kg) showed significantly higher growth performance in terms of FW, WG, and ADG than those of the piglets fed control $(C)$ diet $(p<0.05)$. However, there were no significant differences in growth performance of the piglets fed between the $C$ and T1 $(0.5 \mathrm{~mL} \mathrm{CN} / \mathrm{kg})$ diet groups as well as between the T1 and T2 diet groups. Moreover, no significant difference was observed between FI and ADFI. However, the piglets fed T2 diet showed a significantly higher FE than the piglets fed $\mathrm{C} \operatorname{diet}(p<0.05)$. However, there were no significant differences in terms of FE between the groups of piglets fed C and T1 diets or between the T1 and T2 diets. Likewise, the FCR of piglets fed T2 diet showed a significantly lower value than those in $\mathrm{C}$ diet $(p<0.05)$. However, there were no significant difference in FCR between the groups of the piglets fed C and T1 diets or between T1 and T2 diets. No mortality of piglets was observed throughout the experimental period.

Table 1. Effects of dietary curcumin nanospheres $(\mathrm{CN})$ on growth performance and feed utilization in weaned piglets for 21 -days ${ }^{1}$.

\begin{tabular}{ccccc}
\hline & \multicolumn{3}{c}{ Dietary Treatments } & \\
\cline { 2 - 4 } Items & Control, C & $\begin{array}{c}\text { T1 (0.5 } \mathbf{~ m L} \\
\text { CN/kg) }\end{array}$ & $\begin{array}{c}\text { T2 (1.0 } \mathbf{~} \mathbf{C} \\
\text { CN/kg) }\end{array}$ & $p$-Value \\
\hline FW $^{2}$ & $13.60 \pm 0.04^{\mathrm{b}}$ & $14.66 \pm 0.76^{\mathrm{ab}}$ & $15.44 \pm 0.35^{\mathrm{a}}$ & 0.0098 \\
$\mathrm{WG}^{3}$ & $5.98 \pm 0.55^{\mathrm{b}}$ & $6.92 \pm 0.46^{\mathrm{ab}}$ & $7.68 \pm 0.59^{\mathrm{a}}$ & 0.0228 \\
$\mathrm{ADG}^{4}$ & $0.285 \pm 0.03^{\mathrm{b}}$ & $0.329 \pm 0.02^{\mathrm{ab}}$ & $0.366 \pm 0.03^{\mathrm{a}}$ & 0.0223 \\
$\mathrm{FI}^{5}$ & $9.76 \pm 0.06^{\mathrm{a}}$ & $10.07 \pm 0.45^{\mathrm{a}}$ & $10.65 \pm 0.51^{\mathrm{a}}$ & 0.0778 \\
$\mathrm{ADFI}^{6}$ & $0.465 \pm 0.00^{\mathrm{a}}$ & $0.479 \pm 0.02^{\mathrm{a}}$ & $0.507 \pm 0.02^{\mathrm{a}}$ & 0.0787 \\
$\mathrm{FE}^{7}$ & $61.28 \pm 5.53^{\mathrm{b}}$ & $68.65 \pm 1.60^{\mathrm{ab}}$ & $72.08 \pm 2.18^{\mathrm{a}}$ & 0.0251 \\
FCR $^{8}$ & $1.64 \pm 0.14^{\mathrm{a}}$ & $1.46 \pm 0.03^{\mathrm{ab}}$ & $1.38 \pm 0.04^{\mathrm{b}}$ & 0.0280 \\
\hline
\end{tabular}

1 Values are mean \pm SD from triplicate groups of piglets $(n=3)$ where values in each row with different superscripts are significantly different $(p<0.05)$ and the values in each row with same superscripts are nonsignificantly different. ${ }^{2}$ Final weight $(\mathrm{kg} /$ piglet $) .{ }^{3}$ Weight gain $(\mathrm{kg} /$ piglet $)=($ final weight - initial weight $) /$ initial weight. ${ }^{4}$ Average daily gain. ${ }^{5}$ Feed intake (kg/piglet). ${ }^{6}$ Average daily feed intake; 7 Feed efficiency $(\% /$ pig $)=$ weight gain $\times 100 /$ feed intake. ${ }^{8}$ Feed conversion ratio $=$ feed intake/weight gain. Values in each row with different superscripts ${ }^{\mathrm{a}, \mathrm{b}}$ are significantly different $(p<0.05)$ and the values in each row with same superscripts are non-significantly different.

\subsection{Serum Biochemistry of Piglets}

The effects of dietary $\mathrm{CN}$ on the serum biochemistry of weaned piglets are presented in Table 2. As shown in the table, no significant differences in serum GLU, GGT, TBIL, AMYL, and LYPS contents were observed from the C, T1, and T2 diet groups. The piglets fed T2 diet showed significantly higher CRT contents than those in the C and T1 diets, but no significant difference was observed between $C$ and T1 diets. Significantly higher BUN contents were found in the piglets fed T2 diet than in the $\mathrm{C}$ diet; however, there were no significant differences in BUN contents of the piglets fed $\mathrm{C}$ and T1 diets and between the T1 and T2 diets. Furthermore, there were no significant differences in BUN:CRT among the piglets fed three experimental diets. The piglets fed T2 diet had significantly higher IP and Ca contents than in the $\mathrm{C}$ and T1 diets. However, significantly lower amounts of IP and Ca contents were found in the piglets fed C diet than those in the T1 and T2 diets. Significantly higher T-Pro and ALKP contents were found in piglets fed T2 diet than those 
in the $\mathrm{C}$ and T1 diets, but no significant difference was found between the $\mathrm{C}$ and T1 diet groups. ALT level in piglets fed T2 diet had significantly higher than the piglets fed $C$ and T1 diets. However, there were no significant differences in serum ALT level between the piglets fed C and T1 diets. The serum total cholesterol (TCHOL) content in the piglets fed $\mathrm{C}$ diet was significantly higher than those of the $\mathrm{T} 1$ and $\mathrm{T} 2$ diets, and a significantly lower TCHOL level was found in the piglets fed $\mathrm{T} 2$ diet than those in the $\mathrm{C}$ and $\mathrm{T} 1$ diets. The serum ALB content in the piglets fed T2 diet was significantly higher than the piglets fed $\mathrm{C}$ and $\mathrm{T} 1$ diets. There were no significant differences in serum GLB content among the piglets fed C, T1, and T2 diets. Furthermore, no significant difference in ALB:GLB was found in the piglets fed three experimental diets.

Table 2. Effects of dietary curcumin nanospheres $(\mathrm{CN})$ on serum biochemistry of weaned piglets for 21-days ${ }^{1}$.

\begin{tabular}{ccccc}
\hline & \multicolumn{3}{c}{ Dietary Treatments } & \\
\cline { 2 - 4 } Items & Control, $\mathbf{C}$ & T1 (0.5 $\mathbf{~ m L}$ & T2 (1.0 $\mathbf{~} \mathbf{L}$ & -Value \\
& & CN/kg) & CN/kg) & 0.331 \\
GLU & $107.3 \pm 0.6^{\mathrm{a}}$ & $106.7 \pm 0.6^{\mathrm{a}}$ & $106.7 \pm 0.6^{\mathrm{a}}$ & 0.002 \\
CRT & $1.2 \pm 0.1^{\mathrm{b}}$ & $1.3 \pm 0.1^{\mathrm{b}}$ & $1.5 \pm 0.1^{\mathrm{a}}$ & 0.033 \\
BUN & $7.7 \pm 0.6^{\mathrm{b}}$ & $8.3 \pm 0.6^{\mathrm{ab}}$ & $9.3 \pm 0.6^{\mathrm{a}}$ & 0.448 \\
BUN:CRT & $6.4 \pm 0.3^{\mathrm{a}}$ & $6.2 \pm 0.1^{\mathrm{a}}$ & $6.2 \pm 0.3^{\mathrm{a}}$ & 0.001 \\
IP & $8.7 \pm 0.1^{\mathrm{c}}$ & $9.2 \pm 0.1^{\mathrm{b}}$ & $9.8 \pm 0.1^{\mathrm{a}}$ & 0.001 \\
Ca & $10.3 \pm 0.1^{\mathrm{c}}$ & $11.2 \pm 0.1^{\mathrm{b}}$ & $11.5 \pm 0.2^{\mathrm{a}}$ & 0.001 \\
T-Pro & $6.8 \pm 0.1^{\mathrm{b}}$ & $6.8 \pm 0.1^{\mathrm{b}}$ & $7.0 \pm 0.1^{\mathrm{a}}$ & 0.001 \\
ALB & $2.8 \pm 0.1^{\mathrm{c}}$ & $3.3 \pm 0.2^{\mathrm{b}}$ & $4.2 \pm 0.1^{\mathrm{a}}$ & 0.317 \\
GLB & $4.1 \pm 0.1^{\mathrm{a}}$ & $4.1 \pm 0.1^{\mathrm{a}}$ & $4.0 \pm 0.1^{\mathrm{a}}$ & 0.072 \\
ALB:GLB & $0.7 \pm 0.1^{\mathrm{a}}$ & $0.8 \pm 0.1^{\mathrm{a}}$ & $0.9 \pm 0.1^{\mathrm{a}}$ & 0.015 \\
ALT & $27.0 \pm 1.0^{\mathrm{b}}$ & $30.0 \pm 2.0^{\mathrm{ab}}$ & $33.0 \pm 2.0^{\mathrm{a}}$ & 0.010 \\
ALKP & $85.0 \pm 1.0^{\mathrm{b}}$ & $86.3 \pm 1.0^{\mathrm{b}}$ & $91.0 \pm 1.0^{\mathrm{a}}$ & 1.000 \\
GGT & $8.0 \pm 1.0^{\mathrm{a}}$ & $8.0 \pm 1.0^{\mathrm{a}}$ & $8.0 \pm 1.0^{\mathrm{a}}$ & 0.422 \\
TBIL & $0.4 \pm 0.1^{\mathrm{a}}$ & $0.3 \pm 0.1^{\mathrm{a}}$ & $0.4 \pm 0.1^{\mathrm{a}}$ & 0.001 \\
TCHOL & $145.7 \pm 2.1^{\mathrm{a}}$ & $133.7 \pm 1.5^{\mathrm{b}}$ & $124.7 \pm 1.2^{\mathrm{c}}$ & 0.054 \\
AMYL & $126.3 \pm 1.5^{\mathrm{a}}$ & $123.0 \pm 1.0^{\mathrm{a}}$ & $125.7 \pm 1.5^{\mathrm{a}}$ & 0.230 \\
LYPS & $1339.3 \pm 17.8^{\mathrm{a}}$ & $1335.3 \pm 18.1^{\mathrm{a}}$ & $1358.0 \pm 7.0^{\mathrm{a}}$ &
\end{tabular}

${ }_{1}^{1}$ Values are mean \pm SD from triplicate groups of piglets $(n=3)$ where values in each row with different superscripts $\mathrm{a}, \mathrm{b}, \mathrm{c}$ are significantly different $(p<0.05)$ and the values in each row with same superscripts are non-significantly different. Glu, glucose $(\mathrm{mg} / \mathrm{dL})$; CRT, creatinine $(\mathrm{mg} / \mathrm{dL}) ; \mathrm{BUN}$, blood urea nitrogen $(\mathrm{mg} / \mathrm{dL})$; IP, inorganic phosphorus (mg/dL); Ca, calcium (mg/dL); T-Pro, total protein (g/dL); ALB, albumin (g/dL); GLB globulin (g/dL); ALT, alanine aminotransferase; ALKP, alkaline phosphatase; GGT, gamma-glutamyl transferase; TBIL, total bilirubin; TCHOL, total cholesterol; AMYL, amylase; LYPS, lipase.

\subsection{Serum Proteomics Analysis}

\subsubsection{Identification of Differentially Expressed Proteins (DEPs)}

The serum proteomic profile of the piglets fed $\mathrm{C}$ and $\mathrm{CN}$ containing diets such as $\mathrm{T} 1$ and T2 are presented in Figure 1. The DEPs in the serum of the piglets fed experimental diets were categorized according to the types of protein expressed individually (Figure 1A). Of the identified DEPs, a total of 103 DEPs were found to be significant, of which, 5, 7, and 10 DEPs were uniquely present in the serum of the piglets fed with the C, T1, and T2 diet groups, respectively, whereas 65 DEPs were commonly identified. Likewise, in comparison of the $C$ and T1 diets, the piglets commonly shared the 8 DEPs in the serum and, 3 common DEPs for C and T2 as well as 3 DEPs for T1 and T2 diets (Figure 1A). In addition, we presented a hierarchical clustering heat map of DEPs identified from the proteomic analysis (Figure 1B). The results demonstrated the expression levels of DEPs largely associated with the blood serum of the weaned piglets fed T1 (0.5 mL CN/kg diet) and $\mathrm{T} 2(1.0 \mathrm{~mL} \mathrm{CN} / \mathrm{kg}$ diet) diets in comparison to the C (control) diet. 
(A)

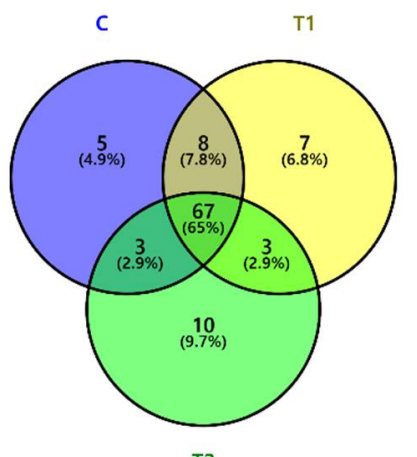

$\mathrm{T} 2$

(B)
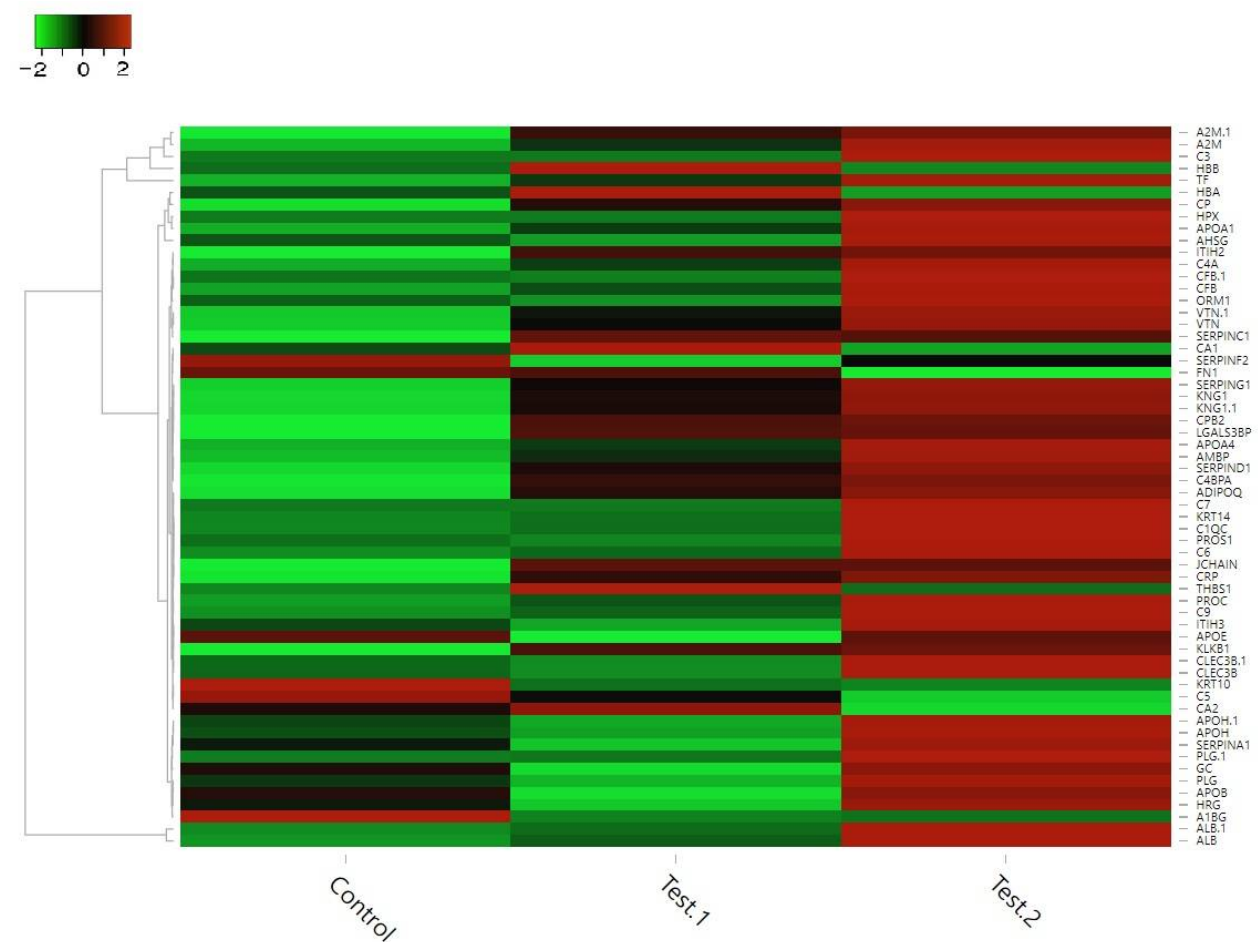

Figure 1. (A) Venn diagrams of the number and percentage of the identified differentially expressed protein (DEPs) and (B) Hierarchical clustering of proteins with significance level $p<0.05$ for comparison of DEPs in the blood serum of the weaned piglets fed C (control), T1 (0.5 mL CN/ kg), and T2 $(1.0 \mathrm{~mL} \mathrm{CN} / \mathrm{kg})$ diets. In heat map, the color scale illustrates the relative expression level of each protein across the samples; red and green colors indicate increased and decreased level of proteins, respectively, compared to the median expression value (black color).

Based on the log fold change in serum DEPs of piglets fed C, T1, and T2 diets, top 18 DEPs are presented in the Table 3. The results revealed that 14 DEPs were upregulated and 4 DEPs were downregulated. Among the upregulated proteins, Alpha-1-acid glycoprotein (ORM1) and Vitamin K-dependent protein S (PROS1) were found to be reduced/deregulated in piglets fed T1 diet; however, the proteins were highly upregulated in piglets fed $\mathrm{T} 2$ diet. 
Table 3. List of differentially expressed proteins (DEPs) identified (Top 18) as upregulated $(\geq 1)$ and downregulated ( $\leq-1)$ proteins based on $\log 2$ fold change, $\log 2(\mathrm{FC})$ data in piglets fed T1 and T2 diets in comparison to the control diet.

\begin{tabular}{|c|c|c|c|c|c|c|}
\hline \multirow{2}{*}{ Regulation } & \multirow{2}{*}{ Acsession Number } & \multirow{2}{*}{ Protein Name } & \multirow{2}{*}{ Gene Symbol } & \multicolumn{2}{|c|}{$\log 2(F C)^{1}$} & \multirow[t]{2}{*}{ Main Function } \\
\hline & & & & T1 & T2 & \\
\hline \multirow[t]{14}{*}{ Up } & F1SJT7 & Apolipoprotein A-IV & APOA4 & 0.92 & 1.96 & Lipid metabolism \\
\hline & F2Z5E2 & Antithrombin-III & SERPINC1 & 7.93 & 7.84 & Regulate blood coagulation \\
\hline & Q9GLP2 & $\begin{array}{l}\text { Vitamin K-dependent } \\
\text { protein C }\end{array}$ & PROC & 3.17 & 5.35 & Regulate blood coagulation \\
\hline & F1SMI8 & Complement C6 & C6 & 1.00 & 3.45 & $\begin{array}{l}\text { Innate and adaptive } \\
\text { immune response }\end{array}$ \\
\hline & A0A4X1U519 & $\begin{array}{l}\mathrm{C} 1 \mathrm{q} \text { domain-containing } \\
\text { protein }\end{array}$ & ADIPOQ & 3.80 & 4.39 & Cellular response to drug \\
\hline & O19062 & Pentaxin & CRP & 2.58 & 3.00 & Innate immune response \\
\hline & F1RUQ0 & Immunoglobulin J chain & JCHAIN & 3.00 & 3.00 & $\begin{array}{l}\text { Secretion of } \operatorname{Ig} \mathrm{A} \text { and } \operatorname{IgM} \\
\text { into mucosa }\end{array}$ \\
\hline & A0A286ZSJ7 & $\begin{array}{c}\text { Complement } \mathrm{C} 1 \mathrm{q} \\
\text { subcomponent subunit } \mathrm{C}\end{array}$ & $\mathrm{C} 1 \mathrm{QC}$ & 1.00 & 4.00 & Innate immune system \\
\hline & A0A287AXN9 & $\begin{array}{l}\text { IF rod domain-containing } \\
\text { protein }\end{array}$ & KRT14 & 1.00 & 4.08 & $\begin{array}{l}\text { Fibrous protein in cells of } \\
\text { skin, hair, nail }\end{array}$ \\
\hline & F1SS26 & Thrombospondin-1 & THBS1 & 4.00 & 1.00 & $\begin{array}{l}\text { Mediates cell-to-cell and } \\
\text { cell-to-matrix interactions }\end{array}$ \\
\hline & F1SMJ6 & $\begin{array}{l}\text { Complement component } \\
\text { C9 }\end{array}$ & C9 & 0.28 & 1.44 & Innate immune system \\
\hline & P48819 & Vitronectin & VTN & 0.74 & 1.29 & $\begin{array}{l}\text { Inhibit cell membrane } \\
\text { damage }\end{array}$ \\
\hline & F1SN68 & Alpha-1-acid glycoprotein & ORM1 & -0.28 & 1.06 & $\begin{array}{l}\text { Transport protein in blood } \\
\text { stream }\end{array}$ \\
\hline & F1SK70 & $\begin{array}{l}\text { Vitamin K-dependent } \\
\text { protein S }\end{array}$ & PROS1 & -0.58 & 2.50 & $\begin{array}{l}\text { Prevent coagulation and } \\
\text { stimulate fibrinolysis }\end{array}$ \\
\hline \multirow[t]{4}{*}{ Down } & F1SS24 & Fibronectin & FN1 & -0.14 & -1.93 & $\begin{array}{l}\text { Blood coagulation, fibrin } \\
\text { cloat formation }\end{array}$ \\
\hline & Q6VPV1 & $\begin{array}{l}\text { Complement } \mathrm{C} 5 \mathrm{a} \\
\text { anaphylatoxin }\end{array}$ & C5 & -0.54 & -1.36 & $\begin{array}{c}\text { Smooth muscle contraction, } \\
\text { basophil and mast cell } \\
\text { degranulation }\end{array}$ \\
\hline & I3LDS3 & Keratin 10 & KRT10 & -1.13 & -1.23 & $\begin{array}{l}\text { Fibrous protein in cells of } \\
\text { skin, hair, nail }\end{array}$ \\
\hline & F1RXC2 & $\begin{array}{c}\text { Carbonic anhydrase } 2 \\
\text { isoform } 1\end{array}$ & CA2 & 0.74 & -4.95 & $\begin{array}{l}\text { Intracellular } \mathrm{pH} \text { regulation } \\
\text { in intestine }\end{array}$ \\
\hline
\end{tabular}

${ }^{1} \mathrm{FC}=$ fold change; $\log 2(\mathrm{FC})$ of $\mathrm{T} 1=\mathrm{T} 1 /$ control; $\log 2(\mathrm{FC})$ of $\mathrm{T} 2=\mathrm{T} 2 /$ control.

\subsubsection{Gene Ontology (GO) Terms of DEPs}

For a better understanding, all data related to the GO terms based on biological processes, cellular components and molecular functions are presented in the Figure 2. In case of the biological processes of the piglets fed $\mathrm{C}$ and $\mathrm{T} 1$ diets, most of the protein functions are related to the negative regulation of catalytic activity and the negative regulation of endopeptidase activity. The piglets fed T1 and T2 diet showed a higher number of proteins functions for both of the activities of biological process compared to the $\mathrm{C}$ diet group (Figure 2). Considering the cellular component (Figure 2), a higher number of proteins found in the extracellular spaces, along with a moderate amount of proteins in cell organelles, but a little amount in the cell cytoskeleton in the piglets fed C, T1, and T2 diets. Based on the GO term analysis, all of the proteins for the cellular component were found to be greater in $\mathrm{T} 1$ than the piglets fed $\mathrm{C}$ diet except for the cell cytoskeleton and organelle in the piglets fed T2 diet (Figure 2). For the molecular function analysis of the DEPs in the piglets fed C, T1, and T2 diets (Figure 2), the results showed that the DEPs were exclusively associated with anion binding, carbohydrate derivative binding, endopeptidase inhibitor activity, enzyme inhibitor activity, and serine-type endopeptidase inhibitor activity, where the number of the proteins were slightly higher in the piglets fed $\mathrm{T} 1$ diet than in the piglets fed C diet. 


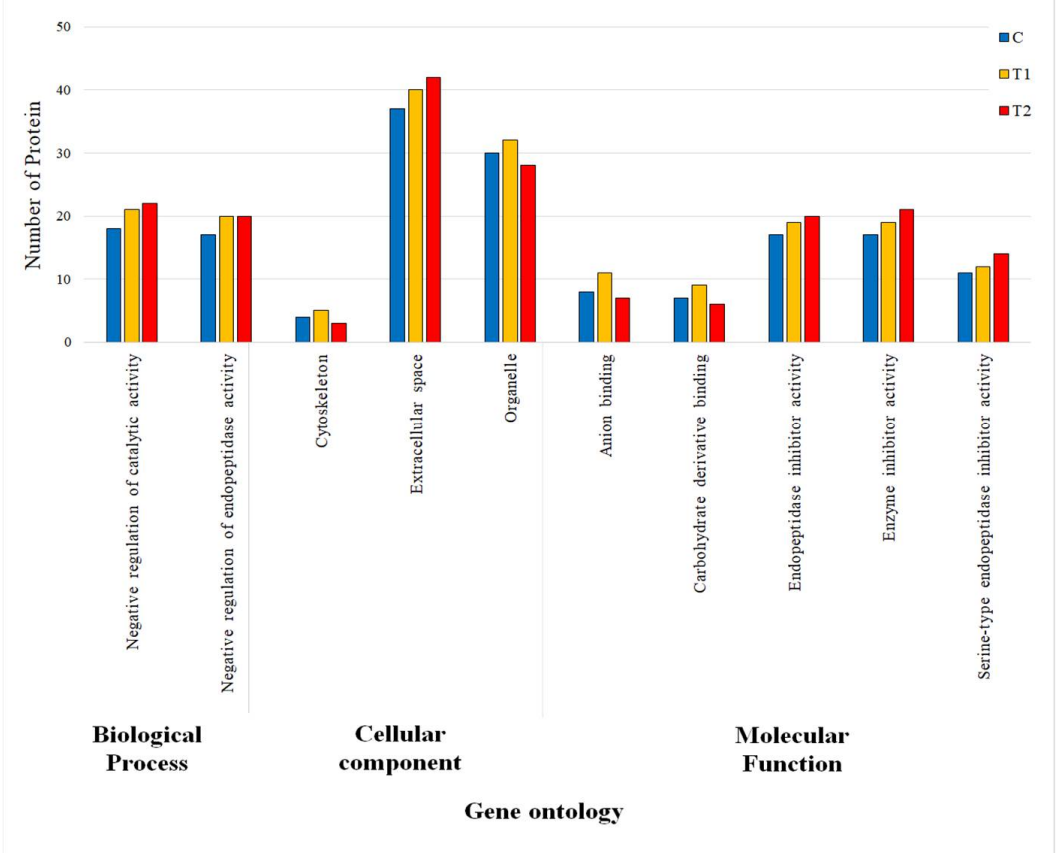

Figure 2. Gene ontology (GO) based on biological processes, cellular components and molecular functions of differentially expressed proteins (DEPs) in the piglets fed C, T1, and T2 diets.

\subsubsection{KEGG and REACTOME Pathway Analyses of DEPs}

After KEGG and REACTOME pathways enrichment analyses for the DEPs in the piglets fed C, T1, and T2 diets (Figure 3), the results of the present study revealed that the KEGG enriched pathway mostly responded to complement and coagulation cascades, nitrogen metabolism, and cholesterol metabolism. The number of proteins associated with complement and coagulation cascades and cholesterol metabolism were found to be higher in piglets fed $\mathrm{T} 1$ and $\mathrm{T} 2$ diets than in the $\mathrm{C}$ diet. On the other hand, the REACTOME pathway associated with the fibrin clot formation, platelet degranulation, post-translational protein phosphorylation, regulation of insulin like growth factor (IGF) transport, and hemostasis. There were no differences in number of proteins related to the REACTOME pathways in piglets fed C, T1, and T2 diets.

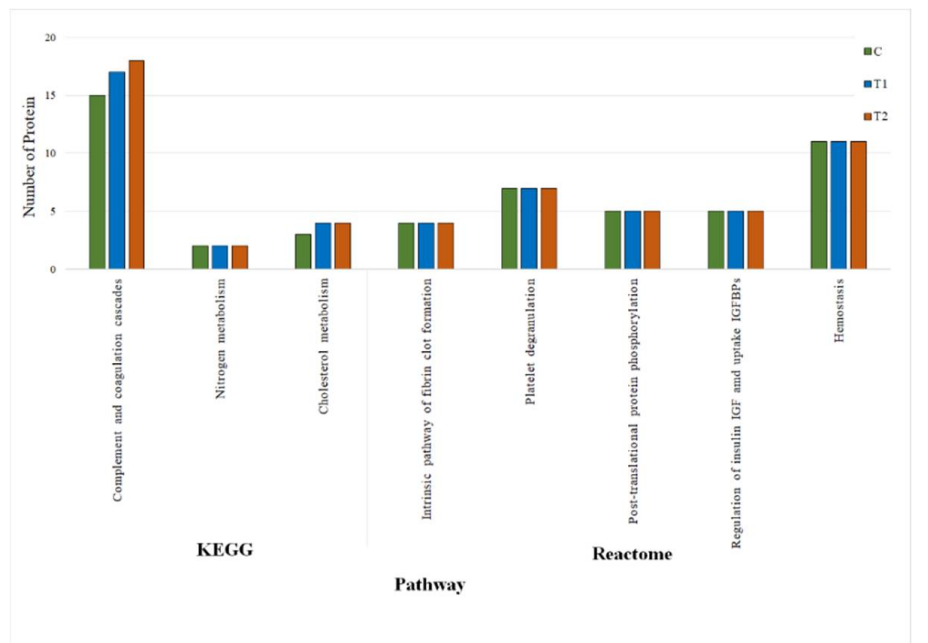

Figure 3. KEGG and REACTOME pathways classification and functional enrichment for the DEPs in the piglets fed $\mathrm{C}, \mathrm{T} 1$, and $\mathrm{T} 2$ diets. 


\subsubsection{Protein-Protein Interaction (PPI) Network of DEPs}

The PPI network analysis was constructed using the online STRING database for the differentially expressed proteins which were altered by the supplementation of $\mathrm{CN}$ in the diets of weaned piglets (Figure 4). The PPI network consisted of 64 nodes and 512 edges. The STRING analysis showed the presence of upregulated and downregulated proteins that mentioned in Table 3. Most of the connected proteins were associated with the stress response, regulation of catalytic activity, and immune response.
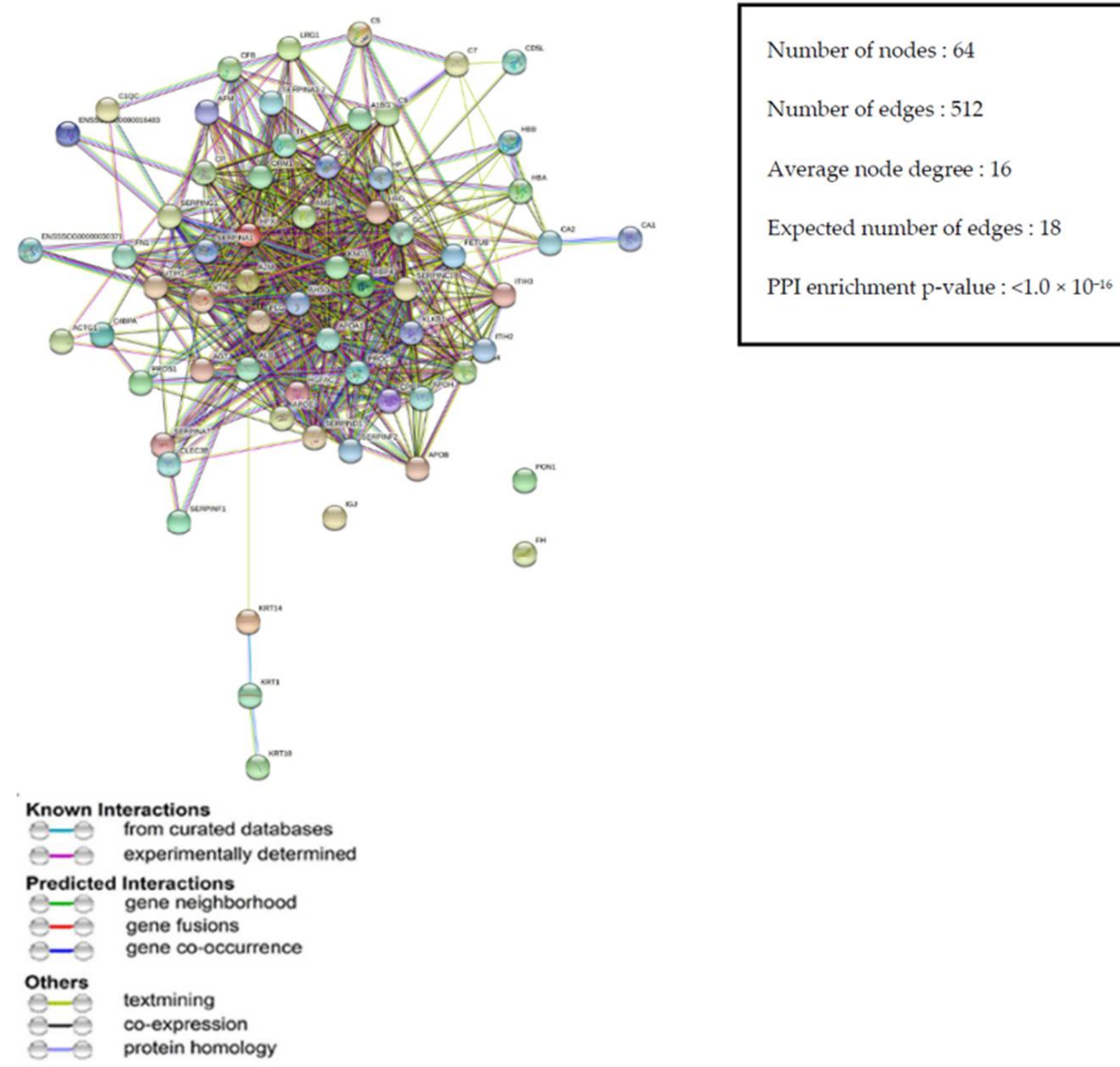

Figure 4. Protein-protein interaction (PPI) network for differentially expressed proteins (DEPs) analyzed by STRING software. The network nodes represent proteins (showing the interactions), and the round nodes denote individual proteins. The line color indicates the type of interaction evidence, and the line thickness indicates the strength of data support.

\subsection{Fecal Coliform Bacteria}

Fecal coliform bacteria were significantly affected by dietary supplementation of $\mathrm{CN}$ in the diets of weaned piglets (Figure 5). At the end of the feeding trial, a significant level of reduction in the numbers of coliform bacterial colonies (CFU/g) was observed in the piglets fed T2 diet compared to the control diet $(p<0.05)$. However, there was no significant difference in fecal coliform bacteria count between the T1 and T2 diet groups $(p>0.05)$. 


\section{COLIFORM BACTERIA}

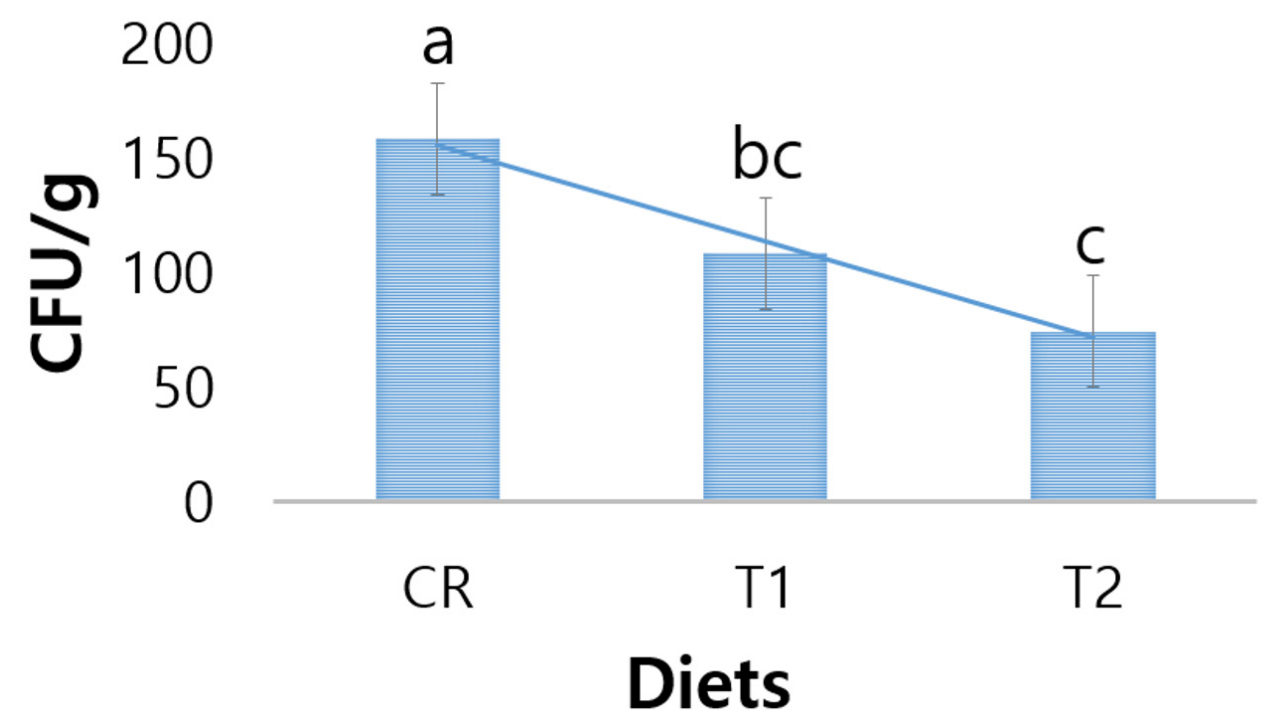

Figure 5. Number of coliform bacteria (CFU/g) in the feces of the weaned piglets fed control (CR), T1 $(0.5 \mathrm{~mL} \mathrm{CN} / \mathrm{kg}$ diet $)$ and $\mathrm{T} 2(1.0 \mathrm{~mL} \mathrm{CN} / \mathrm{kg}$ diet $)$ diets. $(\mathrm{a}, \mathrm{b}, \mathrm{c})$ are significantly different $(p<0.05)$ and the values in each row with same superscripts are non-significantly different.

\subsection{Fecal Ammonia and Hydrogen Peroxide}

The effects of dietary $\mathrm{CN}$ in terms of fecal ammonia $\left(\mathrm{NH}_{3}\right)$ and hydrogen sulfide $\left(\mathrm{H}_{2} \mathrm{~S}\right)$ gas contents in the feces $(25 \mathrm{~g})$ of the weaned piglets are presented in the Table 4 . The results showed that the piglets fed $\mathrm{T} 1$ and $\mathrm{T} 2$ diets had significantly lower fecal $\mathrm{NH}_{3}$ gas contents than those fed $\mathrm{C}$ diet. However, no significant difference in fecal $\mathrm{NH}_{3}$ malodors was observed between the T1 and T2 diet groups. Furthermore, all three groups exhibited a similar level of $\mathrm{H}_{2} \mathrm{~S}$ gas contents in the feces of the weaned piglets.

Table 4. Effects of dietary curcumin nanospheres $(\mathrm{CN})$ on ammonia $\left(\mathrm{NH}_{3}\right)$ and hydrogen sulfide $\left(\mathrm{H}_{2} \mathrm{~S}\right)$ gas contents in feces of weaned piglets for 21-days ${ }^{1}$.

\begin{tabular}{ccccc}
\hline \multirow{2}{*}{ Items } & \multicolumn{3}{c}{ Dietary Treatments } & \\
\cline { 2 - 4 } & Control, C & $\begin{array}{c}\text { T1 (0.5 mL } \\
\text { CN/kg) }\end{array}$ & $\begin{array}{c}\text { T2 (1.0 mL } \\
\text { CN/kg) }\end{array}$ & $p$-Value \\
\hline $\begin{array}{c}\text { Ammonia (ppm) } \\
\begin{array}{c}\text { Hydrogen } \\
\text { sulfide (ppm) }\end{array}\end{array}$ & $6.33 \pm 0.58^{\mathrm{a}}$ & $1.33 \pm 0.58^{\mathrm{b}}$ & $1.67 \pm 0.58^{\mathrm{b}}$ & 0.0001 \\
\hline
\end{tabular}

${ }^{1}$ Values are mean \pm SD from triplicate groups of piglets $(n=3)$ where values in each row with different superscripts are significantly different $(p<0.05)$. Values in each row with different superscripts $\mathrm{a}, \mathrm{b}$ are significantly different $(p<0.05)$ and the values in each row with same superscripts are non-significantly different.

\section{Discussion}

\subsection{Growth Performance of Piglets}

In the pharmacological perspective, the results revealed that the growth performance of the weaned piglets in terms of FW, WG, and ADG were improved with the supplementation of dietary CN at $0.5 \mathrm{~mL}$ (T1) or $1.0 \mathrm{~mL}$ (T2)/ kg diet. Moreover, significantly higher growth performance was observed in the T2 diet group compared with the control diet. In consistent of the present study, in a recent study, Marcon et al. [31] reported that dietary supplementation of curcumin-loaded nanocapsule $(1.89 \mathrm{mg} / \mathrm{kg})$ could significantly enhance the growth in terms of ADG and WG in lambs after a 17-day long experiment. Likewise, Reda et al. [45] reported the positive effects of nanocurcumin on the growth performance and feed utilization in terms of increased WG and decreased FCR in Japanese 
quails which is in agreement with the present study. However, Rahmani et al. [46] did not find any significant difference in the WG of broiler chicken fed high level of nanocurcumin (400 mg/kg diet) compared with the control diet under normal temperature. In case of feed utilization in weaned piglets, the results of the present study revealed that there were no significant differences in terms of FI and ADFI in the piglets fed C, T1, or T2 diets which may attributed to the well acceptance of the supplied experimental feeds and non-toxic effects of feeds by means of $100 \%$ survivability in piglets. Likewise, Marcon et al. [31] and Rahmani et al. [46] did not find any significant differences in the FI of lamb and broiler chicken, respectively, fed control and curcumin-loaded nanocapsule or nanocurcumin supplemented diets. In addition, Marchiori et al. [47] reported that the supplementation of nanocurcumin in the diet of quails can enhance the growth and egg quality of quails in cold stress situation. Furthermore, Lei and Kim [42] found that zinc oxide coated with lipid particle can significantly improve the growth and feed efficiency in young pigs which is in agreement with the present study for nanocurcumin coated with phospholipid in weaned piglets.

\subsection{Serum Biochemistry of Piglets}

Blood serological information can serve as an important tool to ascertain the first line of immunity in living animals. In the present study, serum GLU, GGT, AMYL, and LYPS contents did not significantly vary in the piglets of the control, $\mathrm{T} 1$, and $\mathrm{T} 2$ diet groups. This can be explained by the possibility that the doses of $\mathrm{CN}$ were non-hazardous to the health status and did not affect the digestibility in terms of carbohydrate (amylase, AMYL enzyme activity) and lipid (lipase, LYPS enzyme activity) metabolism. In consistency with our study, Marcon et al. [31] reported that the young lambs fed $1 \mathrm{mg} / \mathrm{kg}$ diet of curcuminloaded nanocapsule did not show any significant changes in serum GLU and GGT levels compared to the control diet. Serum TBIL, ALT, AST, and ALKP are the indicators of liver function where higher levels of these parameters indicate deleterious conditions of the body. In this study, serum TBIL level was not significantly affected by the T1 diet, however, a higher dose of $\mathrm{CN}$ (T2 diet, $1.0 \mathrm{~mL} / \mathrm{kg}$ ) significantly increased the serum ALT and ALKP. According to the ALT and ALKP data in our study, it seemed that higher levels of ALT and ALKP were not toxic to the liver, as reflected by the increment of growth with a significantly higher weight gain in the T2 group compared to the control diet. In consistency with the present study, Marcon et al. [31] found a significantly higher level of AST in lambs fed $2 \mathrm{mg} / \mathrm{kg}$ diet of curcumin-loaded nanocapsule compared with the control diet. Likewise, Reda et al. [45] reported that dietary nanocurcumin at $0.5 \mathrm{~g} / \mathrm{kg}$ of diet could significantly increase the ALT level in Japanese quails as a monogastric animal model, in agreement with the present study. Serum ALB protein helps to balance the blood osmotic pressure between the blood vessels and tissues; and GLB is produced in the liver, which is responsible for proper function of liver, clotting of blood, and fighting against infections. In the present study, serum total protein showed a significantly greater amount in the piglets of the high CN diet, in agreement with Reda et al. [45]. Serum ALB levels were significantly higher in the piglets fed T1 and T2 diets compared to the control diet; however, serum GLB level as well as ALB and GLB ratio were not affected by the dietary treatments. On the contrary, Marcon et al. [31] found no significant difference in serum ALB content in the lambs fed 0 , $1,2,3$, or $4 \mathrm{mg} / \mathrm{kg}$ diet of curcumin-loaded nanocapsule; and serum GLB contents were higher in the lambs fed higher levels of curcumin-loaded nanocapsule. Furthermore, Reda et al. [45] reported significant increment of ALB and GLB levels in the Japanese quails fed higher levels of nanocurcumin in the diets. Serum CRT and BUN are commonly associated with the functions of kidney in animals. Unusually high levels of CRT and BUN in blood serum may indicate the improper functioning of the kidneys. In the present study, the piglets fed higher level of CN showed significantly higher levels of serum CRT and BUN levels. However, CRT and BUN ratio did not show any significant change among the treatment groups, suggesting that the serum CRT and BUN levels were not toxic to the kidney tissues of the animals. In addition, in this study, serum CRT $(1.00-2.60 \mathrm{mg} / \mathrm{dL})$ 
and BUN (8.00-24.0 mg/dL) levels were found to be in suitable ranges for normal pigs based on Mitruka and Rawnsley [48]. In agreement with our study, Marcon et al. [31] found a significantly increased urea contents in lambs supplemented with higher level of nanocurcumin in the diets. However, Reda et al. [45] observed no significant changes in serum CRT and urea contents in the Japanese quails fed nanocurcumin in the diet. Serum electrolytes such as sodium, calcium, chloride, potassium, and phosphorus are known to contribute to maintaining body fluids in living animals. In the current study, serum IP and Ca were found to be significantly higher in the T2 diet which might helped to achieve the highest growth performance and health status among the piglets. Interestingly, TCHOL was significantly reduced in the piglets fed $\mathrm{CN}$ supplemented diets. In line with the present study, Reda et al. [45] also reported that dietary supplementation with nanocurcumin could significantly reduce the total cholesterol levels in the blood serum and the liver of the weaned piglets with intrauterine growth retarded (IUGR). Overall, in the present study, the serum biochemical parameters in weaned piglets fed $\mathrm{C}, \mathrm{T} 1$, and $\mathrm{T} 2$ diets were found to be normal [48].

\subsection{Serum Proteomics of Piglets}

The proteomic profile based on bioinformatics tools in a pre-clinical study on animal model can provide important attributes on the efficacy of biomedicine in terms of physiology, toxicity, and immunity of the animal on molecular level [43]. In the present study, we conducted a comparison based on a proteomic analysis of the blood serum, among the experimental piglet groups through the dietary administration of different $\mathrm{CN}$ levels as opposed to the control diet. We also interpreted the bioinformatics data based on the gene ontology (GO) terms regarding biological processes, cellular components, and molecular functions as well as the pathway enrichment analyses in terms of KEGG and REACTOME pathway associated with the pig, Sus scrofa. The results of the present study indicate that 103 DEPs were highly expressed in serum of the piglets fed C, T1, and T2 diets, of which, 65 DEPs were commonly identified in piglets fed the diets. Likewise, Liu et al. [37] reported 64 DEPs in the piglets fed garlic botanical. In this study, among the 65 DEPs, 18 DEPs were selected where 14 DEPs (APOA4, SERPINC1, PROC, C6, ADIPOQ, CRP, JCHAIN, C1QC, KRT14, THBS1, C9, VTN, ORM1, PROS1) were found to be upregulated and 4 DEPs (FN1, C5, KRT10, CA2) were downregulated based on log fold change of $\geq 1$ (upregulated) or $\leq-1$ (downregulated), in the piglets fed T1 and T2 diets compared to the $C$ diet, respectively. Furthermore, among the 14 upregulated DEPs, there were 7 DEPs such as APOA4, PROC, C6, C1QC, KRT14, VTN, and PROS1 found to be highly upregulated in the blood serum of the weaned piglets fed T2 diet compared to the T1 diet which attributed to the enhancement of health status of pigs.

In this study, based on the biological process of GO terms, most of the proteins involved in negative regulation of endopeptidase activity (GO:0010951) and negative regulation of catalytic activity (GO:0043086) in piglets fed C, T1 and T2 diets; those proteins were highly expressed in the piglets fed $\mathrm{CN}$ supplemented diets compared to the control diet. Regarding cellular components, most of the DE proteins were highly associated with the extracellular space (GO:0005615) outside the plasma membrane occupied by the cell fluid and organelles (GO:0043226) such as the nucleus, mitochondria, vacuoles, vesicles, ribosomes as well as cell cytoskeletons (GO:0005856). Furthermore, the highest amount of protein was found in extracellular spaces in serum of the piglets fed C, T1, and T2 diets. For molecular function, five sets of DEPs were highly expressed for enzyme inhibitor activity (GO:0004857) binding to and stop, prevent or reduces the activity of an enzyme; for anion binding (GO:0043168) interacting with charged atoms or groups of atoms with a net negative charge; for endopeptidase inhibitor activity (GO:0004866) binds to and stop, prevents or reduces the activities of endopeptidase enzymes; for carbohydrate derivative binding (GO:0097367) that interacts selectively or non-covalently with carbohydrate derivatives; and for serine-type endopeptidase inhibitor activity (GO:0004867) binding to and stops, prevents, or reduces the activity of serine-type endopeptidase enzymes. 
In the case of the KEGG pathway enrichment, we identified three significantly enriched pathways such as complement and coagulation cascades, nitrogen metabolism, and cholesterol metabolism. The complement systems are the main parts of innate immune system and coagulation cascades related to blood coagulation or hemostasis [49]. In this study, the complement systems (C6 and C9), and blood coagulating proteins like antithrombinIII (SERPINC1) and vitamin-K-dependent protein C (PROC) were highly upregulated in piglets fed $\mathrm{CN}$ supplemented diets which ultimately increased the health status of piglets in terms of growth performance. Moreover, as the nitrogen metabolism related protein like carbonic anhydrase 2 (CA2) was downregulated and cholesterol metabolism related protein like apolipoprotein A-IV (APOA4) was upregulated, we assumed that these proteins were responsible for reducing ammonia gas contents in feces and cholesterol levels in serum of the piglets fed $\mathrm{CN}$ supplemented diets that have been evidenced in the fecal malodors and serum biochemical assays in the present study. The relation between carbonic anhydrase and ammonia gas is also reported in other findings [50,51]. The REACTOME pathway revealed the five pathways were involved in protein enrichment such as intrinsic pathway of fibrin clot formation, platelet degranulation, post-translational protein phosphorylation related to protein synthesis, regulation of insulin like growth factor (IGF) transport, and uptake related to extracellular region and hemostasis related to systemic blood regulations. Based on the KEGG and REACTOME pathway analyses, we found that majority of the proteins were involved to enhance immune status, high response to drug and metabolism in the piglets fed $\mathrm{CN}$ supplemented diets.

The online STRING network revealed that the upregulated and downregulated proteins were mostly related to the stress response, regulation of catalytic activity, and immune response in terms of upregulating the blood coagulation (SERPINC1, PROC); innate and adaptive immune response (C6, CRP, JCHAIN, C1QC); skeletal protein (KRT14); cellular response to drug (ADIPOQ), lipid metabolism (APOA4), inhibition of cell membrane damage (VTN); and downregulating the fibrin clot formation (FN1), fibrous protein (KRT10), and intracellular $\mathrm{pH}$ in intestine. Overall, the STRING network showed the positive effect of $\mathrm{CN}$ supplementation as a biomedicine in the diet of weaned piglets.

\subsection{Fecal Pathogenic Bacteria of Piglets}

In the weaning period of piglets, diarrhea is the most common medical condition that arises from the significant changes in their gastrointestinal tract (GIT) physiology, microbiology, as well as immunology [48,52]. In this study, fecal coliform bacteria were found to be significantly reduced by the dietary supplementation with $\mathrm{CN}$ in the weaned piglets. In line with our study, Lei and Kim [42] reported that dietary lipid-coated zinc nanoparticles showed a positive effect on reducing fecal coliform bacteria in young pigs challenged with enterotoxigenic E. coli bacteria. Likewise, Rahmani et al. [46] postulated that dietary nanocurcumin can effectively reduce the cecal E. coli populations.

\subsection{Fecal Malodors of Piglets}

The odor emissions from swine farm operations are a major concern worldwide which extremely affects the air quality, quality of human life and health status, and the property values of the houses in the close proximities of the swine farm facilities [53]. In the present study, we found that $\mathrm{CN}$ supplemented diets can reduce the fecal malodors such as $\mathrm{NH}_{3}$ gas of the piglets, thus constituting a great significance in environment friendly rearing of pigs in the farm level. Similarly, in our previous research on $\mathrm{CN}$ effect on mice, we reported that positive effects of the dietary $\mathrm{CN}$ on reducing fecal $\mathrm{NH}_{3}$ gas [54].

\section{Conclusions}

In conclusion-based on the growth, feed utilization, serum biochemistry and proteomics, fecal coliform bacteria and noxious gas like $\mathrm{NH}_{3}$ - the dietary supplementation of $\mathrm{CN}$ can be recommended between $0.5 \mathrm{~mL} / \mathrm{kg}$ and $1.0 \mathrm{~mL} / \mathrm{kg}$ as an alternative of antibiotics for weaned young pigs. The results of the present study demonstrated the successful 
application of nanocurcumin with lipid carriers capable of increasing the growth and production of pigs as well as improving the air environment by reducing malodors. Further studies are warranted for the application of $\mathrm{CN}$ in other animal models in the field of nanobiotechnology.

Author Contributions: Conceptualization, M.M. and T.M.; Methodology, M.M. and T.M.; Software, M.M. and H.K. (Hunhwan Kim); Validation, M.M., H.K. (Hunhwan Kim), G.K. and T.M.; Formal analysis, M.M., H.K. (Hunhwan Kim), H.S., H.K. (Hyunsoo Kim), N.K. and S.C.; Investigation, M.M., H.K. (Hunhwan Kim), H.S., H.K. (Hyunsoo Kim), N.K. and S.C.; Resources, M.M. and T.M.; Data curation, M.M., H.K. (Hunhwan Kim), G.K. and T.M.; Writing-original draft preparation, M.M. and H.K. (Hunhwan Kim); Writing-review and editing, A.K., H.C., G.K. and T.M.; Visualization, M.M., H.K. (Hunhwan Kim), H.C., G.K. and T.M.; Supervision, G.K. and T.M.; Project administration, T.M.; Funding acquisition, T.M. All authors have read and agreed to the published version of the manuscript.

Funding: This work was supported by the Brain Pool Program (grant No. 2019H1D3A1A01101555) for postdoctoral research and the Basic Science Research Program (grant No. 2021R111A1A01052235) through the National Research Foundation of Korea (NRF) funded by the Ministry of Education to Mohammad Moniruzzaman (M.M.), and by the Basic Science Research Program (grant No. 2017R1A2B2007741) to Taesun Min (T.M.) through the National Research Foundation of Korea (NRF), funded by the Ministry of Science, ICT and Future Planning. This work was also supported by National University Development Project funded by the Ministry of Education (Korea) and National Research Foundation of Korea (2021).

Institutional Review Board Statement: The study was conducted according to the guidelines of the Institutional Review Board of the Jeju National University, Jeju City, Korea (approval No. 2021-0055).

Data Availability Statement: All data reported in this article.

Acknowledgments: We would like to greatly acknowledge the National Research Foundation of Korea (NRF), the Ministry of Science, ICT and Future Planning, and the Ministry of Education (Korea) for funding this research work.

Conflicts of Interest: The authors declare no conflict of interest.

\section{References}

1. Moniruzzaman, M.; Min, T. Curcumin, curcumin nanoparticles and curcumin nanospheres: A review on their pharmacodynamics based on monogastric farm animal, poultry and fish nutrition. Pharmaceutics 2020, 12, 447. [CrossRef]

2. Epstein, J.; Sanderson, I.R.; MacDonald, T.T. Curcumin as a therapeutic agent: The evidence from in vitro, animal and human studies. Br. J. Nutr. 2010, 103, 1545-1557. [CrossRef] [PubMed]

3. Karthikeyan, A.; Kim, N.Y.; Moniruzzaman, M.; Beyene, A.M.; Do, K.T.; Senthil, K.S.; Min, T. Curcumin and its modified formulations on inflammatory bowel disease (IBD); the sory so far and future outlook. Pharmaceutics 2021, 12, 447.

4. Karthikeyan, A.; Senthil, N.; Min, T. Nanocurcumin: A Promising Candidate for Therapeutic Applications. Front. Pharmacol. 2020, 11, 487. [CrossRef] [PubMed]

5. Gera, M.; Sharma, N.; Ghosh, M.; Huynh, D.L.; Lee, S.J.; Min, T.; Kwon, T.; Jeong, D.K. Nanoformulations of curcumin: An emerging paradigm for improved remedial application. Oncotarget 2017, 8, 66680-66698. [CrossRef] [PubMed]

6. Prasad, S.; Tyagi, A.K.; Aggarwal, B.B. Recent developments in delivery, bioavailability, absorption and metabolism of curcumin: The golden pigment from golden spice. Cancer Res. Treat. 2014, 46, 2-18. [CrossRef]

7. Zheng, B.; Peng, S.; Zhang, X.; McClements, D.J. Impact of delivery system type on curcumin bioaccessibility: Comparison of curcumin-loaded nanoemulsions with commercial curcumin supplements. J. Agric. Food Chem. 2018, 66, 10816-10826. [CrossRef] [PubMed]

8. Kharat, M.; McClements, D.J. Recent advances in colloidal delivery systems for nutraceuticals: A case study—Delivery by Design of curcumin. J. Colloid Int. Sci. 2019, 557, 506-518. [CrossRef]

9. Wahlstrom, B.; Blennow, G. A study on the fate of curcumin in the rat. Acta Pharmacol. Toxicol. 1978, 43, 86-92. (In Copenh) [CrossRef]

10. Yen, F.L.; Wu, T.H.; Tzeng, C.W.; Lin, L.T.; Lin, C.C. Curcumin nanoparticles improve the physicochemical properties of curcumin and effectively enhance its antioxidant and antihepatoma activities. J. Agric. Food Chem. 2010, 58, 7376-7382. [CrossRef]

11. Yavarpour-Bali, H.; Ghasemi-Kasman, M.; Pirzadeh, M. Curcumin-loaded nanoparticles: A novel therapeutic strategy in treatment of central nervous system disorders. Int. J. Nanomed. 2019, 14, 4449-4460. [CrossRef]

12. Basniwal, R.K.; Buttar, H.S.; Jain, V.K.; Jain, N. Curcumin nanoparticles: Preparation, characterization, and antimicrobial study. J. Agric. Food Chem. 2011, 59, 2056-2061. [CrossRef] 
13. Ohno, M.; Nishida, A.; Sugitani, Y.; Nishino, K.; Inatomi, O.; Sugimoto, M.; Kawahara, M.; Andoh, A. Nanoparticle curcumin ameliorates experimental colitis via modulation of gut microbiota and induction of regulatory T cells. PLOS ONE 2017, 12, e0185999. [CrossRef]

14. Yallapu, M.M.; Nagesh, P.K.B.; Jaggi, M.; Chauhan, S. Therapeutic application of curcumin nanoformulations. AAPS J. 2015, 17, 1341-1356. [CrossRef]

15. Souto, E.B.; Silva, G.F.; Dias-Ferreira, J.; Zielinska, A.; Ventura, F.; Durazzo, A.; Lucarini, M.; Novellino, E.; Santini, A. Nanopharmaceutics: Part I-Clinical Trials Legislation and Good Manufacturing Practices (GMP) of Nanotherapeutics in the EU. Pharmaceutics 2020, 12, 146. [CrossRef]

16. Rai, M.; Pandit, R.; Gaikwad, S.; Yadav, A.; Gade, A. Potential applications of curcumin and curcumin nanoparticles: From traditional therapeutics to modern nanomedicine. Nanotechnol. Rev. 2015, 4, 161-172. [CrossRef]

17. Souto, E.B.; Zielinska, A.; Souto, S.B.; Durazzo, A.; Lucarini, M.; Santini, A.; Silva, A.M.; Atanasov, A.G.; Marques, C.; Andrade, L.N.; et al. (+)-Limonene 1,2-Epoxide-Loaded SLNs: Evaluation of Drug Release, Antioxidant Activity, and Cytotoxicity in an HaCaT Cell Line. Int. J. Mol. Sci. 2020, 21, 1449. [CrossRef]

18. Hu, L.; Jia, Y.; Niu, F.; Jia, Z.; Yang, X.; Jiao, K. Preparation and enhancement of oral bioavailability of curcumin using microemulsions vehicle. J. Agric. Food Chem. 2012, 60, 7137-7141. [CrossRef] [PubMed]

19. Peng, S.; Li, Z.; Zou, L.; Liu, W.; Liu, C.; McClements, D.J. Enhancement of curcumin bioavailability by encapsulation in sophorolipid-coated nanoparticles: An in vitro and in vivo study. J. Agric. Food Chem. 2018, 66, 1488-1497. [CrossRef] [PubMed]

20. Ji, H.; Tang, J.; Li, M.; Ren, J.; Zheng, N.; Wu, L. Curcumin-loaded solid lipid nanoparticles with Brij78 and TPGS improved in vivo oral bioavailability and in situ intestinal absorption of curcumin. Drug Deliv. 2016, 23, 459-470. [CrossRef] [PubMed]

21. Mukerjee, A.; Vishwanatha, J.K. Formulation, characterization and evaluation of curcumin-loaded PLGA nanospheres for cancer therapy. Antican. Res. 2009, 29, 3867-3876.

22. Klippstein, R.; Wang, J.T.W.; El-Gogary, R.I.; Bai, J.; Mustafa, F.; Rubio, N.; Bansal, S.; Al-Jamal, W.T.; Al-Jamal, K.T. Passively targeted curcumin-loaded PEGylated PLGA nanocapsules for colon cancer therapy in vivo. Small 2015, 11, 4704-4722. [CrossRef]

23. Dende, C.; Meena, J.; Nagarajan, P.; Nagaraj, V.A.; Panda, A.K.; Padmanaban, G. Nanocurcumin is superior to native curcumin in preventing degenerative changes in Experimental Cerebral Malaria. Sci. Rep. 2017, 7, 10062. [CrossRef]

24. Shaikh, J.; Ankola, D.D.; Beniwal, V.; Singh, D.; Kumar, M.N.V.R. Nanoparticle encapsulation improves oral bioavailability of curcumin by at least 9 -fold when compared to curcumin administered with piperine as absorption enhancer. Eur. J. Pharm. Sci. 2009, 37, 223-230. [CrossRef]

25. Verma, V.; Ryan, K.M.; Padrela, L. Production and isolation of Pharmaceutical drug nanoparticles. Int. J. Pharm. 2021, 603, 120708. [CrossRef] [PubMed]

26. Takahashi, M.; Uechi, S.; Takara, K.; Asikin, Y.; Wada, K. Evaluation of an oral carrier system in rats: Bioavailability and antioxidant properties of liposome-encapsulated curcumin. J. Agric. Food Chem. 2009, 57, 9141-9146. [CrossRef] [PubMed]

27. Bulboaca, A.E.; Porfire, A.S.; Tefas, L.R.; Boarescu, P.M.; Bolboaca, S.D.; Stanescu, I.C.; Bulboaca, A.C.; Dogaru, G. Liposomal Curcumin is Better than Curcumin to Alleviate Complications in Experimental Diabetic Mellitus. Molecules 2019, $24,846$. [CrossRef]

28. Feng, T.; Wei, Y.; Lee, R.J.; Zhao, L. Liposomal curcumin and its application in cancer. Int. J. Nanomed. 2017, 12, 6027-6044. [CrossRef] [PubMed]

29. Wang, J.; Pan, W.; Wang, Y.; Lei, W.; Feng, B.; Du, C.; Wang, X. Enhanced efficacy of curcumin with phosphatidylserine-decorated nanoparticles in the treatment of hepatic fibrosis. Drug Del. 2018, 25, 1-11. [CrossRef] [PubMed]

30. Rafiee, Z.; Nejatian, M.; Daeihamed, M.; Jafari, S.M. Application of different nanocarriers for encapsulation of curcumin. Crit. Rev. Food Sci. Nutr. 2019, 59, 3468-3497. [CrossRef]

31. Marcon, H.; Griss, L.G.; Molosse, V.L.; Cecere, B.G.O.; Alba, D.F.; Leal, K.W.; Galli, G.M.; Souza, C.F.; Baldissera, M.D.; Gundel, S.; et al. Dietary supplementation with curcumin-loaded nanocapsules in lambs: Nanotechnology as a new tool for nutrition. Anim. Nutr. 2021, 7, 521-529. [CrossRef]

32. Jaguezeski, A.M.; Gündel, S.S.; Favarin, F.R.; Gündel, A.; Souza, C.F.; Baldissera, M.D.; Cazarotto, C.C.; Volpato, A.; Fortuoso, B.F.; Ourique, A.F. Low-dose curcumin-loaded Eudragit L-100-nanocapsules in the diet of dairy sheep increases antioxidant levels and reduces lipid peroxidation in milk. J. Food Eng. 2019, 43, e12942. [CrossRef]

33. Ziegler, A.; Gonzalez, L.; Blikslager, A. Large Animal Models: The Key to Translational Discovery in Digestive Disease Research. Cell. Mol. Gastroenterol. Hepatol. 2016, 2, 716-724. [CrossRef]

34. Pabst, R. The pig as a model for immunology research. Cell Tissue Res. 2020, 380, 287-304. [CrossRef] [PubMed]

35. Swindle, M.M.; Makin, A.; Herron, A.J.; Clubb, F.J., Jr.; Frazier, K.S. Swine as Models in Biomedical Research and Toxicology Testing. Vet. Pathol. 2012, 49, 344-356. [CrossRef] [PubMed]

36. Xun, W.; Shi, L.; Zhou, H.; Hou, G.; Cao, T.; Zhao, C. Effects of curcumin on growth performance, jejunal mucosal membrane integrity, morphology and immune status in weaned piglets challenged with enterotoxigenic Escherichia coli. Int. Immunopharm. 2015, 27, 46-52. [CrossRef] [PubMed]

37. Liu, Y.; Song, M.; Che, T.M.; Bravo, D.; Maddox, C.W.; Pettigrew, J.E. Effects of capsicum oleoresin, garlic botanical, and turmeric oleoresin on gene expression profile of ileal mucosa in weaned pigs. J. Anim. Sci. 2014, 92, 3426-3440. [CrossRef] 
38. Kim, K.; Ji, P.; Song, M.; Che, T.M.; Bravo, D.; Pettigrew, J.E.; Liu, Y. Dietary plant extracts modulate gene expression profiles in alveolar macrophages of pigs experimentally infected with porcine reproductive and respiratory syndrome virus. J. Anim. Sci. Biotechnol. 2020, 11, 74. [CrossRef] [PubMed]

39. Kim, J.Y.; Lee, Y.M.; Kim, D.W.; Min, T.; Lee, S.J. Nanosphere Loaded with Curcumin Inhibits the Gastrointestinal Cell Death Signaling Pathway Induced by the Foodborne Pathogen Vibrio Vulnificus. Cells 2020, 9, 631. [CrossRef] [PubMed]

40. Kim, J.Y.; Min, T.; Lee, S.J. Nanospheres loaded with curcumin promote gut epithelial motility through F-actin-related migration signaling events. J. Nutr. Biochem. 2021, 88, 108555. [CrossRef]

41. Kim, D.W.; Choi, C.-H.; Park, J.P.; Lee, S.-J. Nanospheres Loaded with Curcumin Improve the Bioactivity of Umbilical Cord Blood-Mesenchymal Stem Cells via c-Src Activation during the Skin Wound Healing Process. Cells 2020, 9, 1467. [CrossRef] [PubMed]

42. Lei, X.J.; Kim, I.H. Evaluation of coated zinc oxide in young pigs challenged with enterotoxigenic Escherichia coli K88. Anim. Feed Sci. Technol. 2020, 262, 114399. [CrossRef]

43. Kim, J.A.; Vetrivel, P.; Kim, S.M.; Ha, S.E.; Kim, H.H.; Bhosale, P.B.; Heo, J.D.; Lee, W.S.; Senthil, K.; Kim, G.S. Quantitative Proteomics Analysis for the Identification of Differential Protein Expression in Calf Muscles between Young and Old SD Rats Using Mass Spectrometry. ACS Omega 2021, 6, 7422-7433. [CrossRef] [PubMed]

44. Blum, H.; Beier, H.; Gross, H.J. Improved silver staining of plant proteins, RNA and DNA in polyacrylamide gels. Electrophoresis 1987, 8, 93-99. [CrossRef]

45. Reda, F.M.; El-Saadiny, M.T.; Elnesr, S.S.; Alagawany, M.; Tufarelli, V. Effect of Dietary Supplementation of Biological Curcumin Nanoparticles on Growth and Carcass Traits, Antioxidant Status, Immunity and Caecal Microbiota of Japanese Quails. Animals 2020, 10, 754. [CrossRef]

46. Rahmani, M.; Golian, A.; Kermanshahi, H.; Bassami, M.R. Effects of curcumin and nanocurcumin on growth performance, blood gas indices and ascites mortalities of broiler chickens reared under normal and cold stress conditions. Ital. J. Anim. Sci. 2017, 16, 438-446. [CrossRef]

47. Marchiori, M.S.; Oliveira, R.C.; Souza, C.F.; Baldissera, M.D.; Ribeiro, Q.M.; Wagner, R.; Gundel, S.S.; Ourique, A.F.; Kirinus, J.K.; Stefani, L.M.; et al. Curcumin in the diet of quail in cold stress improves performance and egg quality. Anim. Feed Sci. Technol. 2019, 254, 144-157. [CrossRef]

48. Mitruka, B.M.; Rawnsley, H.M. Clinical Biochemical and Hematological Reference Values in Normal Experimental Animals and Normal Humans; Masson Publishing: Masson, NY, USA, 1981.

49. Amara, U.; Rittirsch, D.; Flier, M.; Bruckner, U.; Klos, A.; Gebhard, F.; Lambris, J.D.; Huber-Lang, M. Interaction Between the Coagulation and Complement System. Adv. Exp. Med. Biol. 2008, 632, 71-79.

50. Boone, C.D.; Gill, S.; Habibzadegan, A.; McKenna, R. Carbonic Anhydrase: An Efficient Enzyme with Possible Global Implications. Int. J. Chem. Eng. 2013, 2013, 813931. [CrossRef]

51. Collett, J.R.; Heck, R.W.; Zwoster, A.J. Dissolved carbonic anhydrase for enhancing post-combustion carbon dioxide hydration in aqueous ammonia. Energy Proc. 2011, 4, 240-244. [CrossRef]

52. Pluske, J.R. Feed- and feed additives-related aspects of gut health and development in weanling pigs. J. Anim. Sci. Biotechnol. 2013, 4, 1-7. [CrossRef] [PubMed]

53. Trabue, S.; Kerr, B.; Bearson, B.; Ziemer, C. Swine odor analyzed by odor panels and chemical techniques. J. Environ. Qual. 2011, 40, 1510-1520. [CrossRef]

54. Park, J.B.; Lee, Y.M.; Park, M.K.; Min, T.S.; Lee, S.J. Effects of anti-ecotoxicological curcumin nanospheres on feed efficiency and fecal odor in mice. J. Environ. Sci. Int. 2019, 28, 183-189. [CrossRef] 